\title{
Gap analyses to assess Canadian readiness for respiratory syncytial virus vaccines: Report from an expert retreat
}

\author{
April Killikelly', Amanda Shane ${ }^{1}$, Man Wah Yeung ${ }^{1}$, Matthew Tunis ${ }^{1}$, Christina Bancej', \\ Althea House', Wendy Vaudry², Dorothy Moore ${ }^{3}$, Caroline Quach ${ }^{4}$
}

\begin{abstract}
Respiratory syncytial virus (RSV) can cause severe disease in infants and older adults. Various vaccine candidates are in development and may become authorized for use in Canada within the next 2-5 years. The Public Health Agency of Canada sought to enhance preparedness for RSV vaccine and passive immunization candidates by organizing an expert retreat to identify knowledge gaps in surveillance and research and development in the context of provincial and territorial RSV public health priorities.
\end{abstract}

We determined that RSV candidate vaccines in development directly address four out of five identified public health priorities, and identified remaining data gaps around vaccine efficacy and effectiveness. We determined that limited or sufficient surveillance data is available to support decision-making for four out of five RSV public health priorities and identified data gaps for several key populations: (i) for RSV cases under 17 years of age, gaps remain for denominator data to calculate incidence and data on medically attended outpatient visits; (ii) for RSV cases in Indigenous and remote communities, gaps remain for data on incidence, prevalence, specific risk factors, feasibility and acceptability; and (iii) for RSV cases in older adults, gaps remain for data on incidence. This process demonstrated the feasibility of, and stakeholder support for, gap analyses in surveillance data to support decisions about prospective vaccines and immune products.
This work is licensed under a Creative Commons Attribution 4.0 International License.

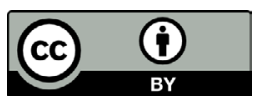

Affiliations

${ }^{1}$ Centre for Immunization and Respiratory Infectious Diseases, Public Health Agency of Canada, Ottawa, ON

2 Stollery Children's Hospital, University of Alberta, Edmonton, $A B$

${ }^{3}$ McGill University, Montreal, QC

${ }^{4}$ Centre Hospitalier Universitaire Sainte-Justine, Université de Montréal, Montreal, QC

\section{*Correspondence:}

phac.naci-ccni.aspc@canada.ca

Suggested citation: Killikelly A, Shane A, Yeung MW, Tunis M, Bancej C, House A, Vaudry W, Moore D, Quach C. Gap analyses to assess Canadian readiness for respiratory syncytial virus vaccines: Report from an expert retreat. Can Commun Dis Rep 2020;46(4):62-8. https://doi.org/10.14745/ccdr.v46i04a02

Keywords: vaccine, National Advisory Committee on Immunization, $\mathrm{NACl}$, immunization, RSV, respiratory syncytial virus

\section{Introduction}

The National Advisory Committee on Immunization ( $\mathrm{NACl}$ ) is Canada's National Immunization Technical Advisory Group (NITAG) and is mandated to provide the Public Health Agency of Canada (PHAC) with technical guidance for vaccine use. When issuing guidance, $\mathrm{NACl}$ considers a broad range of evidence, including the vaccine characteristics, the burden of illness and the ethics, equity, feasibility and acceptability of immunization programs. These factors have all been identified as important drivers for Canadian provincial and territorial $(\mathrm{P} / \mathrm{T})$ decisionmakers (1).

As many respiratory syncytial virus (RSV) vaccines are in clinical development, $\mathrm{NACl}$ needs data on RSV epidemiology and the cost of new vaccine candidates to provide comprehensive guidance addressing these decision drivers. Due to the public health need and the expedited timelines for new vaccine recommendations, PHAC seized the opportunity to enhance RSV vaccine preparedness by hosting an expert gap-analysis retreat to understand the current and future needs of vaccine decisionmakers. The $\mathrm{NACl}$ secretariat, alongside a technical advisory committee (i) coordinated the identification of P/T RSV public health priorities; (ii) selected participants based on their expertise in the fields of RSV surveillance, research, economics, pediatric health and immunization as well as representation from key groups inside and outside of government (see Appendix 1); and (iii) selected industry manufacturers to present on the progress 
of late-stage (Phase 2 or higher) human clinical trials. Industry representatives were invited to present data via teleconference and retreat participants participated in confidential discussions.

\section{Background}

RSV infection represents a large burden of disease in Canada and worldwide. The age distribution of RSV disease burden is bimodal, where the greatest impact is felt in the first two years of life and in older adults. Published Canadian data are lacking, but data from other high-income countries show the following bimodal trend for RSV hospitalization rates per 1,000 people: 26.3 (0-5 months), 11.3 (6-11 months), 1.4 (12-59 months), 1.0 (older than or 65 years) $(2,3)$.

Vaccines targeting maternal, infant or older adult populations have different impacts on RSV prevention in diverse populations. To perform a gap analysis, we first needed to identify and understand the public health priorities (PHPs) for RSV prevention. While vaccine procurement happens federally, vaccine program decision-making and implementation falls within the P/T mandate. To ensure our analysis was relevant and useful for Canadian immunization programs, we focused our attention on alignment with $\mathrm{P} / \mathrm{T}$ public health priorities. In consultation with members of the F/P/T Canadian Immunization Committee and Council of Chief Medical Officers of Health, we developed the following list of the $\mathrm{P} / \mathrm{T}$ public health priorities for RSV vaccine programs:

1. PHP-1: Preventing hospitalization and death in infants

2. PHP-2: Preventing hospitalization and death in high-risk infants

3. PHP-3: Preventing infection in children living in remote settings

4. PHP-4: Preventing hospitalization and death in children

5. PHP-5: Preventing hospitalization and death in older adults

These PHPs for RSV guided the subsequent gap analysis and could enable the creation of vaccine guidance that would suit the needs of $P / T s$.

The objective of the paper is to summarize expert discussion around two topics to inform Canadian RSV vaccine readiness: (i) research and development of vaccine candidates; and (ii) existing public health surveillance. For each of these topics, the alignment with respect to the PHPs was discussed and a gap analysis was performed. The intent of this process is to provide expert rationale for further research and surveillance system development to enhance Canadian RSV vaccine readiness.

\section{Key findings: Research and development of RSV vaccine candidates \\ Alignment of vaccine candidates with public health priorities}

To align RSV vaccine candidates in development with $\mathrm{P} / \mathrm{T}$ public health priorities, we considered the different outcomes of the PHPs: prevention of infection versus prevention of hospitalization or death.

Different vaccine candidate development strategies boost protective immunological responses to either prevent infection, severe disease and/or transmission (4). For vaccine guidance, distinction between these three outcomes is essential. Data that demonstrate that a vaccine prevents severe disease or death may form the evidence base of a recommendation targeting individuals (i.e. clinicians, vaccine recipients). Data that demonstrate that a vaccine prevents infection and/or transmission may form the evidence base of a recommendation targeting the population. These two types of recommendations could potentially have very different funding prioritizations and mechanisms within $P / T$ vaccine programs, impacting who has access to these vaccines and when.

There is a strong foundation of evidence that vaccines that induce protective antibody levels (including subunit vaccines, particle-based vaccines and monoclonal antibodies) prevent severe disease in infants. Vaccines that boost cellular responses (including live attenuated and vectored vaccines) may reduce severe disease as well as viral transmission due to boosting mechanisms related to CD8-mediated viral clearance and shedding.

A population-level vaccine recommendation is supported by an evidence base demonstrating that protective humoral and cellular responses prevent infection and/or transmission on a population-wide level. Otherwise, it may be reasonable to consider indirect evidence from other vaccines that have had an unexpected effect on population-wide transmission. For example, rotavirus vaccine is indicated for the prevention of acute gastroenteritis in children younger than two years old; however, since the vaccine's introduction, rotavirus infection rates in nonvaccinated children and adults have also decreased substantially (5).

We determined that vaccine candidates in development directly address four out of five P/T public health priorities (see Table 1)

Preventing hospitalization and death in infants (PHP-1), high-risk infants (PHP-2) and children (PHP-4): Janssen, GSK and Novavax are developing vaccine candidates that target infant populations either directly or through maternal immunization. AstraZeneca/Sanofi Pasteur is developing a monoclonal antibody to address the burden of RSV disease in 
Table 1: Vaccine candidate gap analysis

\begin{tabular}{|c|c|c|}
\hline PHP & $\begin{array}{l}\text { Provincial/ } \\
\text { territorial PHPs } \\
\text { for RSV }\end{array}$ & $\begin{array}{l}\text { RSV vaccine candidate in } \\
\text { development to address } \\
\text { priority }\end{array}$ \\
\hline 1 & $\begin{array}{l}\text { Preventing } \\
\text { hospitalization and } \\
\text { death in infants }\end{array}$ & $\begin{array}{l}\text { Janssen Junior, GSK Maternal } \\
\text { and Pediatric, Novavax Maternal, } \\
\text { AstraZeneca/Sanofi Pasteur }\end{array}$ \\
\hline 2 & $\begin{array}{l}\text { Preventing } \\
\text { hospitalization and } \\
\text { death in high-risk } \\
\text { infants }\end{array}$ & $\begin{array}{l}\text { Janssen Juniors, GSK Maternal } \\
\text { and Pediatric, Novavax Maternal, } \\
\text { AstraZeneca/Sanofi Pasteur }\end{array}$ \\
\hline 3 & $\begin{array}{l}\text { Preventing infection } \\
\text { in children living in } \\
\text { remote settings }\end{array}$ & AstraZeneca/Sanofi Pasteurb \\
\hline 4 & $\begin{array}{l}\text { Preventing } \\
\text { hospitalization and } \\
\text { death in children }\end{array}$ & AstraZeneca/Sanofi Pasteur \\
\hline 5 & $\begin{array}{l}\text { Preventing } \\
\text { hospitalization and } \\
\text { death in older adults }\end{array}$ & $\begin{array}{l}\text { Janssen Senior, GSK Older Adult, } \\
\text { Novavax Older Adult, Bavarian } \\
\text { Nordic }^{\mathrm{a}}\end{array}$ \\
\hline
\end{tabular}

infants at high risk of severe disease. These vaccine candidates are in Phases 2 and 3 of clinical development for healthy infants; infants at higher risk due to comorbid conditions; and healthy children. These three PHPs are being directly targeted by several vaccine candidates in late-stage clinical development.

\section{Preventing infection in children living in remote settings} (PHP-3): Both vaccines and immune products targeting RSV could address this PHP. Palivizumab is the only product currently available. It is only given to infants at high risk of severe RSV disease or, in the case of a specific pilot project in Nunavik, to all term infants living in remote northern communities (6). The duration of palivizumab activity is approximately one month. The next generation monoclonal antibody products, including the product in development from AstraZeneca/Sanofi Pasteur, may have longer periods of effectiveness (possibility more than five months). This could increase the ease of use of these products in regions with decreased access to health care systems, including remote communities.

Palivizumab and other monoclonal antibodies are expected to prevent severe RSV disease, but it is not known if these products would also reduce RSV infection. Additional research is needed on feasibility and acceptability for RSV vaccine programs in Canadian remote communities. Work is underway in Nunavik, northern Quebec, to assess the impact of expanding access to palivizumab for all infants younger than three months old (6). Although the results of this study will inform decision-making around the use of multidose palivizumab in northern and remote communities, these data may not be directly applicable to new monoclonal antibodies given the potential increase in the duration of protection. Additional studies may be needed to directly address this PHP.
Preventing hospitalization and death in older adults (PHP-5): Janssen, GSK, Novavax and Bavarian Nordic are developing vaccines that target healthy older adults as well as older adults with comorbid conditions, including chronic obstructive pulmonary disease. This PHP is being directly targeted by several vaccine candidates in late-stage clinical development. In addition, this population may be protected by immunization of younger cohorts via herd immunity, similar to rotavirus or pneumococcal disease (5).

\section{Gaps identified for vaccine candidate research and development}

Alongside the gap analysis of $\mathrm{P} / \mathrm{T}$ priorities and vaccine candidates, vaccine manufacturers with late-stage clinical trial programs for a vaccine or immune product targeting RSV were invited to present their data on vaccine effectiveness, safety, immunogenicity and other relevant topics (4). Based on those confidential discussions, we identified areas where additional research or analysis is needed to fully understand the potential efficacy and effectiveness of vaccine candidates in development:

I. Co-administration of RSV vaccines. The antigens presented by multiple candidate vaccines may be the same antigens that are targeted by anti-RSV monoclonal antibodies, including palivizumab. The safety and efficacy of coadministration of vaccines and monoclonal antibodies targeting RSV has not been evaluated.

II. Consistent case definition. Case definitions for RSV outcomes vary across clinical trials. This may limit the head-to-head comparisons of data necessary for guidance synthesis. A consistent and specific RSV-associated illness definition is necessary to be able to compare the efficacy and effectiveness of different RSV candidate vaccines.

III. Protection against RSV/A and RSV/B strains. RSV/A and RSV/B strains are typed on their $G$ surface proteins. Vaccines may have differential efficacy against these strains. Antigenic sites targeted by some of the RSV vaccine candidates are on the $F$ surface protein, specifically antigenic sites $\varnothing$ and $V$, which differ between strains $A$ and $B$ (7). Additional research is necessary to confirm the protective efficacy of these vaccines against both RSV strains.

IV. Impact of pre-existing immunity to adenovirus on vaccine efficacy. Several RSV candidates use vectors from human or chimpanzee adenoviruses to deliver RSV antigens. These vectors may elicit their own immune responses that could dampen or augment immune response to RSV antigens, change the efficacy of the vaccine and/or change the safety profile of the vaccine in previously immune people. Evidence is necessary to determine the prevalence and effect of adenovirus immunity.

V. Impact of potential escape mutants. Palivizumab targets conserved site II on the RSV F protein. Nirsevimab, a novel monoclonal antibody being developed by AstraZeneca/ Sanofi Pasteur and currently in Phase 3 clinical trials, targets site $\varnothing$ on RSV F protein (4). Under conditions of selection pressure, viral variants could change the presentation of 
these antigenic sites (by changing the protein sequence and/or glycosylation patterns) to the degree where these monoclonal antibodies are no longer effective. Surveillance systems would need to be in place to detect these escape mutations in breakthrough infections of monoclonal therapy recipients.

\section{Key findings: Public health surveillance}

\section{Alignment of surveillance with public health priorities}

The surveillance data that inform most PHPs are available from two sources in Canada: an active sentinel hospital surveillance system, the Immunization Monitoring Program ACTive (IMPACT) (8), and a hospital administrative database, the Canadian Institute for Health Information's (CIHI) hospital morbidity database (9). Table 2 shows the extent to which existing national surveillance systems and/or data sources provide evidence for the P/T-defined RSV public health priorities.

Table 2: Extent of available surveillance data to assess effectiveness of RSV vaccine for public health priorities by target groups

\begin{tabular}{|c|c|c|c|c|c|}
\hline \multirow{3}{*}{$\begin{array}{l}\text { Public } \\
\text { health } \\
\text { priority } \\
\text { Infant } \\
\text { hospitalization }\end{array}$} & \multicolumn{5}{|c|}{$\begin{array}{l}\text { Public health parameters } \\
\text { Measures used by } \mathrm{NACl} \text { to assess burden of } \\
\text { illness }\end{array}$} \\
\hline & \multirow{2}{*}{$\begin{array}{l}\text { Incidence } \\
\text { IMPACTC } \\
\mathrm{CIHI}^{\mathrm{C}}\end{array}$} & \multirow{2}{*}{$\begin{array}{l}\text { Study } \\
\text { setting } \\
\text { IMPACTC } \\
\text { CIHIC }^{\mathrm{C}}\end{array}$} & \multirow{2}{*}{$\begin{array}{l}\text { Virus } \\
\text { strain } \\
\text { IMPACT }^{d}\end{array}$} & \multicolumn{2}{|c|}{$\begin{array}{l}\text { High risk } \\
\text { populations }\end{array}$} \\
\hline & & & & IMPACT $^{d}$ & $\left.\mathrm{ClH}\right|^{c}$ \\
\hline Infant death & $\begin{array}{l}\text { IMPACTC } \\
\mathrm{CIHI}^{\mathrm{C}}\end{array}$ & $\begin{array}{l}\text { IMPACTC } \\
\text { CIHII }^{\mathrm{C}}\end{array}$ & IMPACT $^{d}$ & IMPACT $^{d}$ & $\left.\mathrm{ClH}\right|^{c}$ \\
\hline $\begin{array}{l}\text { Infection } \\
\text { in remote } \\
\text { communities } \\
\text { (child) }\end{array}$ & $\begin{array}{l}\text { IMPACT }^{\mathrm{M}} \\
\mathrm{CIHI}^{\mathrm{C}}\end{array}$ & $\begin{array}{l}\text { IMPACTC } \\
\text { CIHII }^{C}\end{array}$ & $\mathrm{IMPACT}^{\mathrm{C}}$ & \multicolumn{2}{|c|}{$\begin{array}{c}\mathrm{IMPACT}^{\mathrm{C}} \\
\mathrm{CIHI^{ \textrm {c } }}\end{array}$} \\
\hline $\begin{array}{l}\text { Child } \\
\text { hospitalization }\end{array}$ & $\begin{array}{l}\text { IMPACTC } \\
\text { CIHIC }^{C}\end{array}$ & $\begin{array}{l}\text { IMPACTC } \\
\text { CIHIC }^{C}\end{array}$ & IMPACT $^{d}$ & IMPACT $^{d}$ & $\left.\mathrm{ClH}\right|^{\mathrm{c}}$ \\
\hline Child death & $\begin{array}{l}\text { IMPACTC } \\
\text { CIHIC }^{\mathrm{C}}\end{array}$ & $\begin{array}{l}\text { IMPACTC } \\
\text { CIHIC }\end{array}$ & IMPACT $^{d}$ & IMPACT $^{d}$ & $\left.\mathrm{ClH}\right|^{\mathrm{c}}$ \\
\hline $\begin{array}{l}\text { Senior } \\
\text { hospitalization }\end{array}$ & $\mathrm{ClHI}$ & $\mathrm{ClHI}$ & NDe & \multicolumn{2}{|c|}{$\mathrm{ClHI}$} \\
\hline Senior death & $\mathrm{ClHI}$ & $\mathrm{ClHI}$ & $N D^{e}$ & \multicolumn{2}{|c|}{$\left.\mathrm{ClH}\right|^{c}$} \\
\hline \multicolumn{6}{|c|}{$\begin{array}{l}\text { Abbreviations: CIHI, Canadian Institute for Health Information; IMPACT, Immunization Monitoring } \\
\text { Program ACTive; NACI, National Advisory Committee on Immunization; ND, no data; RSV, } \\
\text { respiratory syncytial virus } \\
\text { a Study settings may include: community, primary care, hospital, nosocomial } \\
\text { b High risk populations for RSV include: infants, children and seniors with underlying medical } \\
\text { conditions } \\
\text { c Limited data - yellow } \\
\text { d Sufficient data - grey } \\
\text { e No data - pink }\end{array}$} \\
\hline
\end{tabular}

Three PHAC surveillance experts jointly conducted a subjective assessment of each system/data source to determine whether adequate, limited or no data exist to support decision-making. IMPACT was able to provide sufficient data on viral strain characteristics and high-risk pediatric populations (infants and children hospitalized with RSV in IMPACT centres). IMPACT was able to provide limited data on incidence and infection in remote communities, and no data on RSV-associated illness not requiring hospitalization. Incidence rates are difficult to calculate for some sites because the site catchment areas do not align with population statistics (see Table $\mathbf{3}$ for more information). As there are no IMPACT sites in the three territories or northern areas of affected provinces, RSV cases in these communities would only be captured if patients were transferred to an IMPACT hospital. Study setting is limited to hospital wards and intensive care units.

\section{Table 3: Overview of surveillance gaps in assessing data available for priority populations}

\begin{tabular}{|c|c|c|}
\hline $\begin{array}{l}\text { Prio } \\
\text { popul }\end{array}$ & Data gap & Proposed gap-filling strategy \\
\hline \multirow{2}{*}{$\begin{array}{l}\text { Cases under } \\
17 \text { years of } \\
\text { age }\end{array}$} & $\begin{array}{l}\text { Denominator } \\
\text { data }\end{array}$ & $\begin{array}{l}\text { lospital-level linkage of IMPACT } \\
\text { entres with } \mathrm{ClHI}\end{array}$ \\
\hline & $\begin{array}{l}\text { ally } \\
\text { SV } \\
\text { ata }\end{array}$ & None pro \\
\hline $\begin{array}{l}\text { Cases in } \\
\text { Indigenous } \\
\text { and remote } \\
\text { communities }\end{array}$ & $\begin{array}{l}\text { Incidence, } \\
\text { prevalence or } \\
\text { specific risk } \\
\text { factor data }\end{array}$ & $\begin{array}{l}\text { Surveillance pilot projects may } \\
\text { clarify the burden of disease, } \\
\text { acceptability and feasibility of } \\
\text { vaccine programs in these at-risk } \\
\text { communities }\end{array}$ \\
\hline $\begin{array}{l}\text { Cases in older } \\
\text { adults }\end{array}$ & $\begin{array}{l}\text { Incidence, } \\
\text { prevalence, } \\
\text { strain or } \\
\text { specific risk } \\
\text { factor data }\end{array}$ & $\begin{array}{l}\text { Retrospective cohort study of } \\
\text { laboratory-confirmed RSV by } \\
\text { CIRN-SOS } \\
\text { Prospective surveillance through a } \\
\text { sentinel surveillance network }\end{array}$ \\
\hline \multicolumn{3}{|c|}{$\begin{array}{l}\text { Abbreviations: CIHI, Canadian Institute for Health Information; CIRN-SOS, Canadian Immunization } \\
\text { Research Network Severe Outcome Surveillance; IMPACT, Immunization Monitoring Program } \\
\text { ACTive; RSV, respiratory syncytial virus }\end{array}$} \\
\hline \multicolumn{3}{|c|}{$\begin{array}{l}\text { CIHI was able to provide limited data on hospitalizations for all } \\
\text { public health parameters, across all ages, but not viral strain } \\
\text { characteristics. The extent of data availability through } \mathrm{CIHI} \text { was } \\
\text { assessed as limited because viral testing is not always performed } \\
\text { at acute care hospitals (9), and modelling is required to estimate } \\
\text { hospitalizations due to RSV. Data for high-risk populations are } \\
\text { also available from CIHI, but these data are limited by the way } \\
\text { in which comorbid conditions are captured in administrative } \\
\text { databases. The most responsible diagnosis and } 24 \text { other } \\
\text { diagnosis fields can be scanned for comorbid conditions, but the } \\
\text { use of these fields is variable based on clinical need. }\end{array}$} \\
\hline
\end{tabular}

\section{Data gaps within three priority populations}

The retreat participants identified three priority populations for which more data are needed (see Table 3).

I. Under 17 years of age:

a. Lack of denominator data: The IMPACT system aims to provide data on RSV hospitalizations of children aged 16 years and younger. However, it is a sentinel (and not population-based) surveillance system, and catchment areas for some sites are not aligned with available population data. Therefore, current data from this system are limited to the number of health events (e.g. number of 
admissions, number of deaths, number of intensive care unit admissions). Interpretation of these indicators without the context of the population from which these are derived is difficult and would be improved with calculation of population-based indicators. Hospital-level linkage of IMPACT centres with hospital administrative data from $\mathrm{CIHI}$ may be explored to conduct trend validation, compare patient numbers captured by different data sources, examine representativeness/comprehensiveness of this sentinel networks and ascertain denominator data.

b. Lack of non-medically attended RSV infection data: No data are available for non-medically attended RSV infection, as would be needed for RSV transmission models and cost-effectiveness studies. No gap-filling strategy was proposed at the retreat.

II. Indigenous and remote communities: Indigenous and remote communities face additional barriers to accessing healthcare and are underrepresented in current national surveillance systems. Estimates of the incidence, prevalence or specific risk factors are not systematically available for Indigenous communities. The IMPACT system captures patients from Indigenous and remote communities who are hospitalized or transferred to an IMPACT site, but these data do not reflect the true burden of illness in this community. Surveillance pilot projects are under way in Quebec in some remote Indigenous communities to determine the burden of disease, acceptability and feasibility of vaccination programs (6). The changing landscape of vaccine products available to prevent RSV represents opportunities for longer-lasting and more durable products. Further study is needed to ascertain the needs of Indigenous and remote communities.

III. Older adults: National data on RSV infection in older adults are limited to hospital administrative data from $\mathrm{CIHI}$. Evidence suggests that crude RSV counts and rates derived from hospital administrative data in Canada underestimate the burden of illness in older adults because of incompleteness of viral testing in this age group (10). Despite limitations of missing data, administrative data remain an important source of data. Primary data collection of epidemiology and burden of disease inputs is warranted for evaluations in older adults. Two strategies to address this need were proposed during the discussions:

a. A retrospective cohort study of laboratory-confirmed RSV in patients 65 years and older hospitalized for influenza-like illnesses (ILI) is underway via the Canadian Immunization Research Network Severe Outcome Surveillance network (11). The ability of this dataset to fill existing data gaps for older adults could be explored.

b. The feasibility of establishing prospective surveillance for RSV in older adults through a sentinel surveillance network could be explored.

Additional surveillance systems limitations were discussed:

- Understanding the long-term sequelae of RSV helps in the development of vaccination programs and economic models. Current data about the role of RSV in the development of chronic obstructive pulmonary disorder or asthma are inconclusive. Additional studies are needed to further understand this link and the long-term burden of RSV illness.

- $\quad$ Some respiratory and RSV surveillance systems use case definitions of ILI to define their target populations. The drivers for this are often either opportunistic (RSV systems leverage existing influenza surveillance infrastructure and ILI definitions to identify suspect cases) or practical (individuals selected for specimen collection are based on existing clinical testing algorithms or standards of care). The inclusion of fever in the ILI case definition may result in missed RSV cases; however, there is no standard syndromic case definition for RSV infection. To address this issue, PHAC participated in an international World Health Organizationled collaboration to develop an RSV surveillance case definition and will endeavour to apply this case definition in PHAC-led surveillance initiatives or analyses (12).Current surveillance systems are based on passive surveillance of those seeking medical attention for RSV. To estimate the burden of non-medically attended RSV, an active surveillance strategy would be needed. Although the feasibility of this approach is complex, these data are essential to build accurate RSV transmission and economic models.

\section{Strengths and limitations}

Although the above analyses provide expert rationale for future study and pursuit of gap-filling strategies, there are some caveats to our approach. First, the analyses are limited by the expertise of the participants in the room. The number of participants was incomplete due to the feasibility of hosting an in-person, roundtable discussion. As a result, these analyses do not represent an exhaustive analysis of the field as a whole.

Second, the PHPs identified in collaboration with $\mathrm{P} / \mathrm{Ts}$ are representative of a spectrum of regional needs. Although consensus was achieved in advance of the retreat, we recognize that these priorities do not represent each community, province or territory and these analyses should be considered a rough estimate rather than a precise fit.

Finally, the field of RSV vaccine and monoclonal antibody development is moving at such a fast pace that this report will be out-of-date before it goes to press. However, even as vaccine candidate development is proceeding, the discussion of alignment with PHPs and identification of data gaps will guide the field towards more efficacious and effective vaccines.

\section{Conclusion}

This retreat demonstrated the feasibility and stakeholder appetite for discussing prospective vaccines. This retreat has provided valuable insight into what public health parameters are 
2. Shi T, McAllister DA, O'Brien KL, Simoes EA, Madhi SA, Gessner BD, Polack FP, Balsells E, Acacio S, Aguayo C, Alassani I, Ali A, Antonio M, Awasthi S, Awori JO, Azziz-Baumgartner E, Baggett HC, Baillie VL, Balmased A, Barahona A, Basnet S, Bassat Q, Basualdo W, Bigogo G, Bont L, Breiman RF, Brooks WA, Broor S, Bruce N, Bruden D, Buchy P, Campbell S, Carosone-Link P, Chadha M, Chipeta J, Chou M, Clara W, Cohen C, de Cuellar E, Dang DA, Dash-Yandag B, Deloria-Knoll M, Dherani M, Eap T, Ebruke BE, Echavarria M, de Freitas Lázaro Emediato CC, Fasce RA, Feikin DR, Feng L, Gentile A, Gordon A, Goswami D, Goyet S, Groome M, Halasa N, Hirve S, Homaira N, Howie SR, Jara J, Jroundi I, Kartasasmita CB, Khuri-Bulos N, Kotloff KL, Krishnan A, Libster R, Lopez O, Lucero MG, Lucion F, Lupisan SP, Marcone DN, McCracken JP, Mejia M, Moisi JC, Montgomery JM, Moore DP, Moraleda C, Moyes J, Munywoki P, Mutyara K, Nicol MP, Nokes DJ, Nymadawa P, da Costa Oliveira MT, Oshitani H, Pandey N, Paranhos-Baccalà G, Phillips LN, Picot VS, Rahman M, Rakoto-Andrianarivelo M, Rasmussen ZA, Rath BA, Robinson A, Romero C, Russomando G, Salimi V, Sawatwong P, Scheltema N, Schweiger B, Scott JA, Seidenberg P, Shen K, Singleton $R_{\text {, }}$ Sotomayor V, Strand TA, Sutanto A, Sylla M, Tapia MD, Thamthitiwat S, Thomas ED, Tokarz R, Turner C, Venter M, Waicharoen S, Wang J, Watthanaworawit W, Yoshida LM, Yu H, Zar HJ, Campbell H, Nair H; RSV Global Epidemiology Network. Global, regional, and national disease burden estimates of acute lower respiratory infections due to respiratory syncytial virus in young children in 2015: a systematic review and modelling study. Lancet 2017 Sep;390(10098):946-58. DOI PubMed

\section{Acknowledgements}

Captured here is a summary of a discussion and analysis from many participants of the RSV Vaccine Readiness Retreat, including N Crowcroft, G De Serres, N Gnidziejko, J Langley, J LeBlanc, M Naus, J Papenburg, E Rafferty and G Poliquin. We gratefully acknowledge their essential contributions to this analysis. The authors would also like to acknowledge the significant contribution of S Sandhu in informing the RSV surveillance landscape and gap analysis during Retreat preparations and execution.

\section{Funding}

The Public Health Agency of Canada hosted the in-person meeting on site and covered the travel costs of participants.

\section{References}

1. Erickson LJ, De Wals P, Farand L. An analytical framework for immunization programs in Canada. Vaccine 2005 Mar;23(19):2470-6. DOI PubMed

3. Shi T, Denouel A, Tietjen AK, Campbell I, Moran E, Li X, Campbell H, Demont C, Nya-wanda BO, Chu HY, Stoszek SK, Krishnan A, Openshaw P, Falsey AR, Nair H; RESCEU Investigators. RESCEU Investigators. Global disease burden estimates of respiratory syn-cytial virus-associated acute respiratory infection in older adults in 2015: a systematic re-view and meta-analysis. J Infect Dis 2019 Mar:jiz059. DOI PubMed

4. Killikelly A, Tunis M, House A, Quach C, Vaudry W, Moore D. Overview of the respiratory syncytial virus vaccine candidate pipeline in Canada. Can Commun Dis Rep 2020;46(4):56-61. DOI

5. Wilson SE, Rosella LC, Wang J, Le Saux N, Crowcroft NS, Harris T, Bolotin S, Deeks SL. Population-level impact of Ontario's infant rotavirus immunization program: evidence of direct and indirect effects. PLoS One 2016 May;11(5):e0154340. DOI PubMed

6. Gilca R, Billard M, Lorcy A, Rochette M, Papenburg J, Zafack J, Charest H, Dionne M, Boucher F, De Serres G. Evaluation of new palivizumab immunoprophylaxis recommenda-tions in Nunavik infants: results for 2014 to 2017. Quebec City (QC): Bibliothèque et Archives nationales du Québec: Institut national de santé publique Québec (INSPQ); 2018. https://nrbhss.ca/sites/default/files/ documentations/report_palivizumab_immunoprophylaxis_ nunavik_infants.pdf 
7. Hause AM, Henke DM, Avadhanula V, Shaw CA, Tapia LI, Piedra PA. Sequence variabil-ity of the respiratory syncytial virus (RSV) fusion gene among contemporary and historical genotypes of RSV/A and RSV/B. PLoS One 2017 Apr;12(4):e0175792. DOI PubMed

8. Canada's immunization monitoring program ACTive (IMPACT). Ottawa (ON): Canadian Paediatric Society; 2019 (Accessed 2019-12-20). https://www.cps.ca/en/impact

9. Hospital morbidity database. Ottawa (ON): Canadian Institute for Health Infor-mation; 2019 Nov (Accessed 201912-20). https://www.cihi.ca/en/hospital-morbidity-database
10. Schanzer DL, Saboui M, Lee L, Nwosu A, Bancej C. Burden of influenza, respiratory syn-cytial virus, and other respiratory viruses and the completeness of respiratory viral identi-fication among respiratory inpatients, Canada, 20032014. Influenza Other Respir Viruses 2018 Jan;12(1):113-21. DOI PubMed

11. Serious outcomes surveillance (SOS) network. Halifax (NS): CIRN; 2019 (Accessed 2019-12-20). http://cirnetwork.ca/ network/serious-outcomes/

12. WHO global RSV surveillance pilot - objectives [Internet]. Geneva (CH): World Health Organization; (Accessed 201912-20). https://www.who.int/influenza/rsv/rsv_objectives/en/

\section{Appendix 1: RSV Vaccine Readiness Retreat participant list}

\begin{tabular}{|c|c|}
\hline Name & Professional affiliation \\
\hline Caroline Quach & Université de Montréal, Centre hospitalier universitaire (CHU) Sainte-Justine \\
\hline Sarah Buchan & Public Health Ontario \\
\hline Natasha Crowcroft & Public Health Ontario \\
\hline Gaston De Serres & Institut national de santé publique du Québec (INSPQ) \\
\hline Shelley Deeks & Public Health Ontario \\
\hline Nick Gnidziejko & Canadian Institute for Health Information $(\mathrm{ClHI})$ \\
\hline Joanne Langley & Dalhousie University and the Canadian Immunization Research Network (CIRN) \\
\hline Jason LeBlanc & Nova Scotia Health Authority \\
\hline Dorothy Moore & McGill University \\
\hline Monika Naus & British Columbia Centre for Disease Control (BCCDC) \\
\hline Jesse Papenburg & McGill University \\
\hline Ellen Rafferty & University of Alberta \\
\hline Beate Sander & Toronto Health Economics and Technology Assessment (THETA) \\
\hline Wendy Vaudry & University of Alberta \\
\hline Christina Bancej & Centre for Immunization and Respiratory Infectious Diseases (CIRID), Surveillance and Epidemiology Division (SED) \\
\hline Erin Henry & CIRID \\
\hline Althea House & CIRID, National Advisory Committee on Immunization (NACl) Secretarait \\
\hline April Killikelly & CIRID-NACI Secretariat \\
\hline Robert Nesdole & First Nations and Inuit Health Branch (FNIHB) \\
\hline Linda Pelude & $\begin{array}{l}\text { Centre for Communicable Diseases and Infection Control (CCDIC) - Canadian Nosocomial Infections Surveillance } \\
\text { Program (CNISP) }\end{array}$ \\
\hline Robert Pless & Health Canada, Biological and Genetic Therapies Directorate (BGTD) \\
\hline Guillaume Poliquin & National Microbiology Laboratory (NML) \\
\hline Simran Sandhu & CIRID, SED \\
\hline Amanda Shane & CIRID, SED \\
\hline Veeran-Anne Singh & FNIHB \\
\hline Matthew Tunis & CIRID, NACI Secretariat \\
\hline Man Wah Yeung & CIRID, NACI Secretariat \\
\hline
\end{tabular}

